\title{
Peningkatan Kemampuan Penyusunan Laporan Keuangan Sesuai Standar Akuntansi bagi Pelaku UMKM di Provinsi Banten
}

\author{
Iis Solihat $^{{ }^{*}}$, Pesi Suryani ${ }^{2}$, Olivia Idrus ${ }^{3}$, Any Meilani ${ }^{4}$, Amalia Kusuma Wardini ${ }^{5}$ \\ Jurusan Akuntansi, Fakultas Ekonomi, Universitas Terbuka ${ }^{1,2,3,5}$ \\ Jurusan Ekonomi Pembangunan, Fakultas Ekonomi, Universitas Terbuka ${ }^{4}$ \\ isolihat@ecampus.ut.ac.id ${ }^{1}$,pesi@ecampus.ut.ac.id ${ }^{2}$, olivia@ecampus.ut.ac.id ${ }^{3}$, \\ any@ecampus.ut.ac.id ${ }^{4}$, amalia@ecampus.ut.ac.id ${ }^{5}$
}

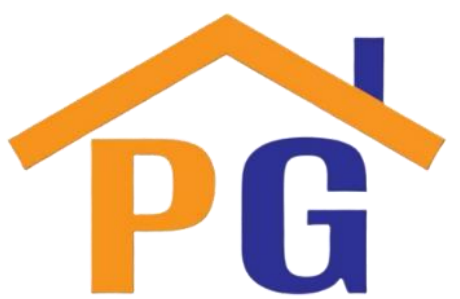

Riwayat Artikel

Diterima pada 30 Oktober 2021

Revisi 1 pada 19 November 2021

Revisi 2 pada 23 Januari 2022

Disetujui pada 23 Januari 2022

\begin{abstract}
Abstrak
Purpose: Community service activity by Lecturers of Accounting Study Program of Universitas Terbuka (UT) aims to provide training for the community of Micro, Small, and Medium Enterprises (MSMEs) in making financial reports in accordance with accounting standards for MSMEs. This is conducted to solve the problems faced by MSMEs who still have a lot of difficulties in recording and reporting financial statements, which ultimately has an impact on the difficulty of obtaining credit from financial institutions.
\end{abstract}

Method: This activity was attended by MSMEs from Banten Province and consisted of several stages, namely (1) planning, through discussions with MSMEs, (2) presentation from speakers, answering questions and discussions through web seminars in the Zoom application as well as live streaming in UT's youtube channel and (3) mentoring the making of financial reports to five participants who answered the quiz.

Result: The results of community service activities show that MSMEs are able to enable the preparation of SAK ETAP MSME financial statements in the form of general journals, adjustment journals, ledgers, balance sheets, working papers, income statements of MSME actors ready to develop and successfully get capital assistance from financial institutions.

Conclusion: This exercise is highly valuable for participants and stimulates them, according to the comments received from them. And it is believed that with the help of financial statements, banks, and non-bank financial institutions would be able to give loans to MSMEs.

Keywords: Accounting standards, Financial statements, MSMEs How to Cite: Solihat, I., Suryani, P., Idrus, O., Meilani, A., dan Wardini, A, K. (2022). Peningkatan Kemampuan Penyusunan Laporan Keuangan Sesuai Standar Akuntansi bagi Pelaku UMKM di Provinsi Banten. Jurnal Nusantara Mengabdi, 1(2), 77-83.

\section{Pendahuluan}

Pemerintah Indonesia telah berkomitmen untuk terus meningkatkan pendanaan bagi Usaha Mikro, Kecil, dan Menengah (UMKM), yang dianggap sebagai tulang punggung perekonomian karena memberikan pergerakan yang signifikan terhadap pembangunan ekonomi dan kesempatan kerja (Badria \& Diana, 2018). Menurut rilis data dari Kementerian Koordinator Bidang Perekonomian Republik Indonesia pada 5 Mei 2021, usaha mikro, kecil, dan menengah (UMKM) menjadi pilar paling signifikan dari perekonomian Indonesia karena sekitar 99 persen perusahaan Indonesia berbentuk UMKM. Sebuah laporan terbaru dari Menteri Koperasi dan UKM Indonesia menunjukkan bahwa pelaku UMKM di negara ini telah mencapai 64,2 juta orang, dengan kontribusi terhadap PDB sebesar 61,07 persen, atau total nilai 8.573,8 miliar rupiah (US\$1,1 miliar) (Kemenkoekonomi RI, 2021). UMKM memberikan 
kontribusi yang signifikan bagi perekonomian Indonesia, terlihat dari kemampuannya menyerap 97 persen dari seluruh tenaga kerja dan menghimpun hingga 60,4 persen dari total investasi di tanah air.

Keunggulan sektor UMKM lainnya yakni telah teruji dapat melewati berbagai kondisi krisis. Di Indonesia sendiri UMKM dapat bertahan dari krisis pada tahun 1998, 2008 dan pada situasi pandemik Covid-19 seperti yang terjadi sekarang ini. UMKM mengalami penurunan permintaan yang signifikan dan mengakibatkan penurunan pendapatan. Pada saat yang sama, dengan diberlakukannya pembatasan sosial berskala besar (psbb), mereka menghadapi kehilangan pasokan tenaga kerja yang cepat karena keterbatasan mobilitas. Dalam hal pendapatan, sekitar dua pertiga UMKM kehilangan uang selama epidemi. Selama krisis, lebih dari 80\% UMKM mengalami penurunan margin keuntungan, dan sekitar 53\% mengalami penurunan nilai aset (UNDP \& LPEM UI, 2020). Untuk bertahan dari pandemi COVID-19, banyak UMKM harus beradaptasi dan mengubah operasi bisnis mereka. Namun, gerakan seperti itu seringkali membutuhkan keterampilan yang saat ini tidak tersedia bagi pelaku UMKM. Di titik inilah, seluruh komponen pemerintahan termasuk perguruan tinggi memainkan peran penting dengan memberikan pelatihan-pelatihan penting bagi UMKM misalnya, pelatihan internet marketing, bisnis digital, dan pembuatan laporan keuangan secara efektif dan efisien. Pelatihan dapat diberikan dalam program pengabdian kepada masyarakat yang rutin diselenggarakan secara periodik.

Menurut Undang-Undang Republik Indonesia Nomor 20 Tahun 2008 Tentang Usaha Mikro, Kecil, dan Menengah, UMKM adalah usaha kecil yang dimiliki dan dikelola oleh seorang individu atau sekelompok kecil individu yang memiliki tingkat kekayaan dan pendapatan tertentu. Berdasarkan aset dan omsetnya, berikut ini adalah kriteria seleksi untuk UKM dan perusahaan besar.

Tabel 1. Klasifikasi UMKM berdasarkan aset dan omset

\begin{tabular}{|c|c|c|}
\hline \multirow{2}{*}{$\begin{array}{c}\text { Jenis klasifikasi } \\
\text { besarnya usaha }\end{array}$} & \multicolumn{2}{|c|}{ Indikator } \\
\cline { 2 - 3 } & Aset tidak bergerak & $\begin{array}{c}\text { Omset } \\
\text { (per 12 bulan) }\end{array}$ \\
\hline Usaha Mikro & $<50$ juta & $<300$ juta \\
\hline Usaha Kecil & 51 juta -500 juta & 300 juta $-2,5$ miliar \\
\hline Usaha Menengah & 501 juta -10 miliar & 2,5 miliar -50 miliar \\
\hline Usaha Besar & $>10$ miliar & $>50$ miliar \\
\hline
\end{tabular}

Data dari Kementerian Koperasi dan UMKM Republik Indonesia pada tahun 2021 menunjukkan terdapat 422.369 unit UMKM tersebar di seluruh wilayah Provinsi Banten (Kemenkop UKM RI, 2021). Salah satu asosiasi yang menaungi pelaku UMKM yakni Komunitas Pengusaha Muda Banten (KPMB) yang juga merupakan sasaran kegiatan pengabdian kepada masyarakat. Usaha kecil dan menengah (UKM) sering mengalami kesulitan dalam operasi mereka dalam hal pencatatan dan pelaporan keuangan. Karena kurangnya pengetahuan dan persepsi bahwa akuntansi itu sulit, banyak usaha kecil dan menengah (UKM) belum menerapkan informasi keuangan ke bisnis mereka atau memelihara catatan akuntansi di usaha mereka (Widaninggar \& Sari, 2018).

Pada tahun 2009 pedoman penyelenggaraan akuntansi bagi sektor UMKM disusun oleh Dewan Standar Akuntansi Keuangan (DSAK). Tujuannya untuk mengidentifikasi, mengukur, dan melaporkan transaksi keuangan dalam laporan keuangan. Standar Akuntansi Keuangan Entitas Tanpa Akuntabilitas Publik (SAK ETAP) ini lebih mudah dibandingkan dengan SAK biasa. SAK ETAP dirancang untuk diimplementasikan oleh entitas yang bebas dari tanggung jawab kepada khalayak luas. Selain itu, perusahaan ini hanya menyiapkan laporan keuangan untuk tujuan umum untuk pihak luar seperti lembaga pemberi pinjaman. SAK ETAP adalah versi SAK Umum yang lebih sederhana dan tidak terlalu 
canggih. Selain SAK ETAP, kemudahan akuntansi lainnya bagi UMKM adalah semakin beragamnya pilihan software akuntansi (Widyastuti, 2017). Kedepannya, UMKM diharapkan dapat memelihara pembukuan dan menghasilkan laporan keuangan, sehingga mempermudah pendanaan bagi usaha UMKM (Risal, Wulandari, \& Jaurino, 2020).

Persepsi mereka sebelumnya tentang pencatatan dan pembukuan sebagai hal yang sulit, memakan waktu, dan menantang menjadi hambatan untuk belajar akuntansi (Pustapa, Riandra, \& Aisyah, 2019). Oleh karena itu, pencatatan akuntansi berbasis teknologi menjadi sangat penting, khususnya bagi UMKM. Pemahaman atas penggunaan SAK ETAP yang merupakan standar akuntansi yang dirancang untuk digunakan oleh organisasi komersial yang tidak bertanggung jawab kepada publik, tentu akan sangat membantu. Kendala lainnya yang dihadapi pelaku UMKM yakni belum tersedianya pelatihan pengelolaan keuangan usaha yang memanfaatkan program tersebut. Perlu adanya penyuluhan dan bantuan pengelolaan keuangan bagi pelaku UMKM (Rudiantoro \& Siregar, 2012).

ILO (2019) berpendapat usaha kecil dan menengah (UKM) di Indonesia harus berupaya menjadi lebih "bankable" agar dapat mengakses layanan keuangan. Usaha kecil dan menengah (UKM) harus mengembangkan sikap yang lebih profesional alih-alih melihat organisasi mereka sebagai perpanjangan dari kegiatan keluarga mereka. Sebuah rencana bisnis, yang mencakup informasi tentang operasi perusahaan, barang, staf, pemasaran, dan prosedur, biasanya penting. Banyak usaha kecil dan menengah (UKM) membutuhkan akuntansi perusahaan yang efektif, dengan arus kas didokumentasikan dan kemampuan untuk merencanakan pengembangan untuk mengadopsi pendekatan yang lebih kewirausahaan. Namun, kurangnya keahlian dan pemahaman mereka tentang akuntansi, khususnya pencatatan dan pembukuan untuk pembuatan laporan keuangan, terbukti sering menjadi masalah dalam menjadikan mereka naik kelas dan bankable. Hal ini sangat relevan dengan hasil studi IFC (2016) yang menyebut permasalahan utama UMKM di Indonesia yakni akses kepada lembaga keuangan.

UMKM juga perlu membuat strategi bisnis jangka menengah hingga panjang untuk meminimalkan dampak COVID-19 pada perusahaan mereka. Mayoritas UKM ingin membentuk dana cadangan. Ini adalah dua strategi yang digunakan untuk menjamin bahwa mereka akan mampu mengatasi jika dan ketika epidemi atau krisis lain terjadi di masa depan. UNDP dan LPEM UI (2020) memperkirakanan jumlah uang atau modal kerja yang dibutuhkan, lebih dari $43 \%$ perusahaan membutuhkan dana tambahan Rp 100 hingga 500 juta, sementara sepertiga UMKM menginginkan modal kerja Rp50-100 juta. Selain itu, baik UMKM milik perempuan maupun laki-laki membutuhkan jumlah pembiayaan tambahan yang hampir sama.

Untuk menjawab tantangan di atas, Jurusan Akuntansi Universitas Terbuka mengambil bagian dalam memberi pemahaman dan keterampilan khususnya dalam penyusunan laporan keuangan bagi pelaku UMKM. Kegiatan ini dikemas dalam program pengabdian kepada masyarakat. Benefit atau keuntungan program ini bagi perguruan tinggi dan peserta antara lain adalah pengembangan kelembagaan dan pendidikan yang berkualitas khususnya dalam meningkatkan kemampuan UMKM untuk mengidentifikasi dan memberikan solusi permasalahan sebagai dasar analisis dalam menyikapi fenomena pelaporan keuangan bagi UMKM.

Terungkap beberapa UMKM mengatakan bahwa penyusunan laporan keuangan dan permodalan yang sesuai dengan saran stakeholders dan kebutuhan masyarakat menjadi salah satu hal yang perlu diperhatikan dalam menentukan kegiatan pengabdian kepada masyarakat oleh Jurusan Akuntansi, berdasarkan permasalahan yang dihadapi oleh pelaku UMKM. Selain itu, sebagaimana dikemukakan oleh sebagian besar responden UMKM, aspek-aspek juga diperhatikan agar hasil kegiatan pengabdian masyarakat meninjau kondisi lokasi tempat program dijalankan, analisis kebutuhan peserta, sarana prasarana, masukan pemangku kepentingan, dan kebutuhan pendidikan tinggi.

Tridharma telah menjadi jiwa perguruan tinggi Indonesia. Pendidikan, penelitian, dan pengabdian kepada masyarakat merupakan tiga pilarnya. Dharma pertama harus didasarkan pada gagasan membangun dan mendidik sumber daya manusia jangka panjang. Melalui penelitian dan pengembangan, dharma kedua harus mampu memperluas kapasitas untuk menghasilkan ilmu 
pengetahuan dan teknologi baru. Terakhir, dharma ketiga digunakan untuk memberikan kontribusi bagi kemajuan bangsa dengan mentransfer ilmu pengetahuan dan teknologi kepada masyarakat luas. Secara individu atau bekerjasama dengan pihak lain, kegiatan tridharma akan mampu menghasilkan karya intelektual yang dapat dikomunikasikan kepada khalayak umum melalui karya tulis ilmiah, seminar, paten, lisensi, buku, tulisan populer, dan sebagainya. Secara terpisah, ketiga dharma tersebut harus dipandang sebagai suatu totalitas yang kohesif.

Kegiatan pengabdian masyarakat yang dilakukan oleh perguruan tinggi, sebagaimana telah disampaikan sebelumnya, harus selalu berorientasi pada kegiatan yang berdampak langsung dan bermanfaat bagi khalayak luas (Noor, 2010). Ketercapaian ini menjadi esensial sebab tujuan pengabdian kepada masyarakat adalah untuk: (a) mengakselerasi upaya penguatan keterampilan masyarakat pengguna sejalan dengan visi yang diusung daerah tersebut; dan (b) Meningkatkan kegiatan pengembangan masyarakat dalam rangka mewujudkan masyarakat yang dinamis dan siap beradaptasi dengan perubahan guna menjadi lebih baik dan maju sejalan dengan cita-cita masyarakat yang berlaku. (c) Meningkatkan laju pengembangan masyarakat dan pertumbuhan profesional sejalan dengan proses modernisasi.

Pembangunan masyarakat menuju masyarakat yang maju dan modern jelas memerlukan upaya kelembagaan dan profesional. Kegiatan pengabdian masyarakat universitas juga dimaksudkan agar mendapat input yang konkret bagi pengembangan desain pembelajaran di universitas terkait, sehingga desain pembelajaran ini lebih menjawab kebutuhan masyarakat itu sendiri (Riduwan, 2016). Juga diyakini bahwa pengabdian masyarakat akan mengalihkan fokus civitas akademika dari isu-isu yang muncul dalam kehidupan masyarakat (Utama \& Pratama, 2019). Pejabat universitas dapat menggunakan berbagai kriteria untuk mendefinisikan dan memprioritaskan tujuan pengabdian masyarakat yang disebutkan di atas dengan lebih baik. Kriteria ini dapat mencakup, tetapi tidak terbatas pada: struktur ilmiah universitas; anggaran dasar dan rencana induknya; lingkungan ekonomi, sosial, dan budaya masyarakat setempat; tingkat pembangunan daerah atau negara; dan/atau faktor lain yang relevan.

Tujuan penyampaian laporan keuangan kepada pihak eksternal adalah untuk menghimpun dana tambahan dan memperluas perusahaan. Dari sisi keuangan, sektor UMKM mengalami kesulitan. Bank dan lembaga keuangan bukan bank tidak akan memberikan kredit atau kredit kepada pelaku UMKM; Sebaliknya, sektor perbankan biasanya akan menentukan apakah akan memberikan kredit kepada pelaku UMKM berdasarkan kajian terhadap laporan keuangan yang telah dihasilkan.

Berangkat dari uraian permasalahan di atas, tim Pengabdian kepada Masyarakat Program Studi Akuntansi Fakultas Ekonomi Universitas Terbuka tertarik untuk meningkatkan kemampuan khususnya dalam penyusunan laporan keuangan dalam bentuk kegiatan pelatihan. Kedepannya, para pelaku UMKM yang tergabung dalam Asosiasi Pengusaha Muda Banten (KPMB) Banten diharapkan dapat menyusun akuntansi keuangan secara akurat, sesuai dengan kebutuhan laporan, sehingga dapat digunakan untuk mengajukan pinjaman bank dan untuk evaluasi. kinerja UMKM.

\section{Metode}

Objek atau sasaran Pengabdian Kepada Masyarakat ini adalah para pelaku UMKM di berbagai Kota/Kabupaten Provinsi Banten. Selain itu, kegiatan ini juga terlaksana atas kerjasama dengan Komunitas Pengusaha Muda Banten (KPMB). Mitra adalah asosiasi pelaku usaha kecil, mikro dan menengah di Provinsi Banten yang menggeluti berbagai bidang usaha, seperti usaha makanan, tekstil, percetakan dan lain-lain. Mitra terlibat secara aktif dalam semua kegiatan, serta ikut serta dalam kegiatan pelatihan dan pendampingan penyusunan laporan keuangan sesuai standar akuntansi. Rangkaian program pengabdian diakhiri dengan pendampingan mengenai pencatatan akuntansi berupa penyusunan laporan keuangan sesuai dengan standar akuntansi yang berlaku untuk jenis Usaha Mikro, Kecil dan Menengah (SAK UMKM) agar usaha mitra tersebut dapat survive dan bersaing dengan usaha lainnya yang sejenis, selain itu Laporan keuangan nanti juga dapat digunakan sebagai syarat pengajuan dana pada lembaga perbankan. 
Teknik pelaksanaan kegiatan pengabdian masyarakat ini dilakukan secara daring dengan memanfaatkan aplikasi Zoom dengan tautan https://sl.ut.ac.id/Abdimas-AKT-030721 dan Live Streaming Channel Youtube Universitas Terbuka karena adanya pandemi Covid-19 dan wajib mengikuti standar kesehatan selama pandemi. Tujuan pelatihan ini tetap tersampaikan meski dilaksanakan secara virtual dan tidak tatap muka. Pelatihan diselenggarakan sesuai rencana yakni pada hari Sabtu tanggal 3 Juli 2021 pukul 09.00 WIB - 12.00 WIB.

Materi pelatihan dan pendampingan disusun sedemikian rupa secara bertahap agar mitra dapat menyerap dengan baik materi yang diberikan. Dimulai dari materi pengenalan akuntansi dan manfaatnya dalam dunia usaha, hingga pada materi puncak yakni penyusunan laporan keuangan. Materi dirumuskan berdasarkan kebutuhan mitra. Adapun materi pelatihan dan pendampingan yang diberikan kepada para pelaku UMKM dapat dilihat pada tabel 2.

Tabel 2. Jabaran materi pelatihan

\begin{tabular}{|l|l|}
\hline \multicolumn{1}{|c|}{ Materi } & \multicolumn{1}{c|}{ Tujuan } \\
\hline $\begin{array}{l}\text { Pengenalan Pentingnya } \\
\text { Akuntansi }\end{array}$ & $\begin{array}{l}\text { Memberikan pemahaman kepada pelaku UMKM mengenai } \\
\text { pentingnya pencatatan akuntansi dalam pengelolaan usaha }\end{array}$ \\
\hline Basis Pencatatan Akuntansi & $\begin{array}{l}\text { Peserta pelatihan memahami basis pencatatan yang digunakan } \\
\text { dalam akuntansi, yaitu terdiri dari basis kas dan basis aktual }\end{array}$ \\
\hline Persamaan Akuntansi & $\begin{array}{l}\text { Peserta pelatihan mampu mengidentifikasikan dan menyusun } \\
\text { persamaan akuntansi }\end{array}$ \\
\hline Siklus Akuntansi & $\begin{array}{l}\text { Peserta pelatihan mampu memahami siklus akuntansi yang ada } \\
\text { pada usaha yang sedang dijalankan, meliput materi tentang } \\
\text { bagaimana menganalisis bukti transaksi yang ada hingga } \\
\text { penyusunan Laporan keuangan sederhana untuk UMKM }\end{array}$ \\
\hline Laporan Keuangan & $\begin{array}{l}\text { Peserta pelatihan mampu menyusun Laporan keuangan sederhana } \\
\text { untuk UMKM meliputi laporan laba rugi, laporan neraca atau } \\
\text { posisi keuangan dan Laporan arus kas. }\end{array}$ \\
\hline
\end{tabular}

Materi pelatihan dan pendampingan disusun sedemikian rupa mulai dari tahapan dasar filosofinya, kenapa usaha mikro perlu menyusun laporan keuangan, dengan meninjau manfaat yang dapat mereka peroleh, hingga pada tahapan penyusunan laporan keuangan. Elemen penting yang juga harus dicatat adalah utang dan piutang. Utang dan piutang dicatat dalam buku yang terpisah sehingga memudahkan mitra menelusuri utang-piutangnya, mengetahui jatuh tempo utang-piutang, dan kapan harus melakukan pembayaran utang atau penagihan piutang.

\section{Hasil dan pembahasan}

Membentuk kepanitiaan dan menyusun rancangan kegiatan dalam bentuk proposal untuk memutuskan topik dalam penyelenggaraan program pengabdian masyarakat merupakan langkah awal dalam melaksanakan kegiatan pengabdian kepada masyarakat. Setelah menentukan tim pelaksana dan tema pelaksanaan, tim mengkoordinir pelatihan awal KKN daring pembuatan laporan keuangan sesuai standar akuntansi bagi pelaku UMKM di Provinsi Banten, mengidentifikasi capaian serta sasaran pelaku UMKM yang dipilih ikut serta dalam pelatihan,. Setelah beberapa kali pertemuan dengan organisasi UMKM Banten, Komunitas Pengusaha Muda Banten (KPMB), ditetapkan bahwa pengabdian masyarakat prodi Akuntansi akan dilakukan secara online dan live melalui channel Youtube UT (https://www.youtube.com/tonton?v=vHDIHLVnvnE). 


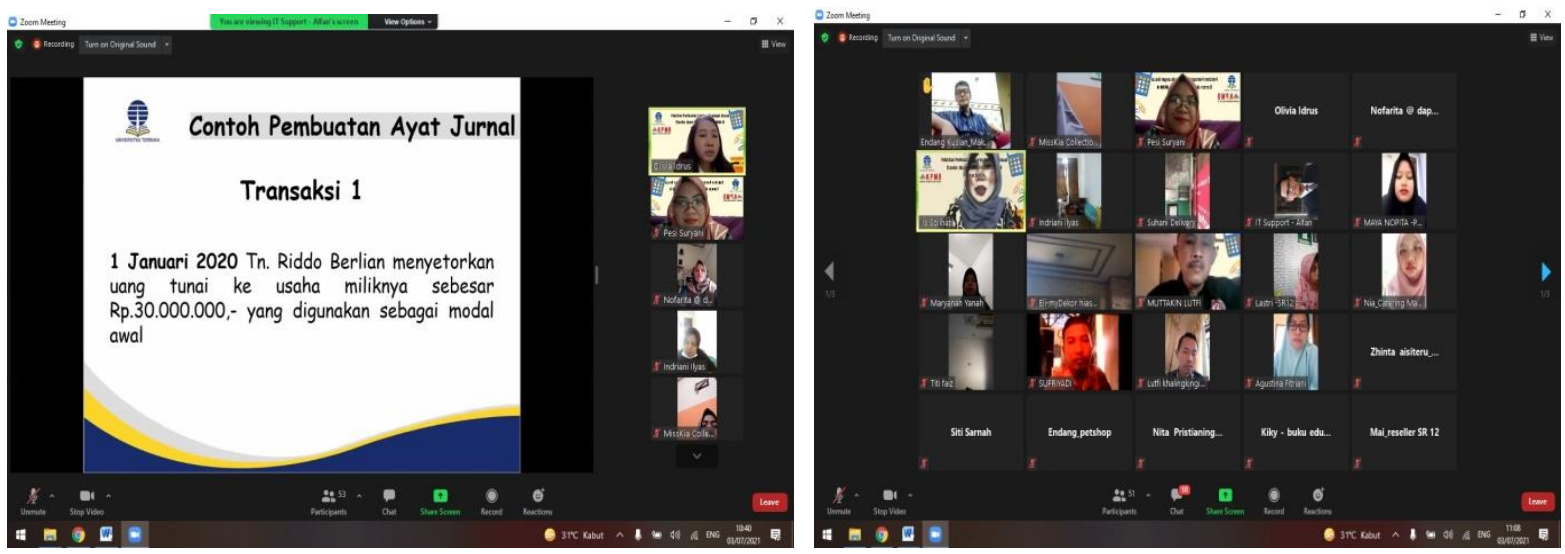

Gambar 1. Kegiatan pelaksanaan pelatihan secara daring

Organisasi UMKM Banten, Komunitas Pengusaha Muda Banten (KPMB), dipilih sebagai peserta bukan hanya karena ada UMKM yang membutuhkan pelatihan pembuatan laporan keuangan, tetapi juga karena mereka merupakan komunitas UMKM yang masih awam dengan pembuatan laporan keuangan. Tim pengabdian kepada masyarakat proyek pengabdian masyarakat prodi Akuntansi kemudian berkoordinasi dengan para pelaku UMKM di lingkungan KPMB. Untuk menentukan kriteria UMKM yang akan didorong dan diajar oleh tim, diperlukan kerjasama sebagai salah satu fase awal dalam prosesnya. Selain itu, penyuluh pengabdian masyarakat bertanggung jawab atas kerjasama internal untuk menghasilkan materi dan sumber daya yang akan digunakan untuk pelatihan UMKM setelah infrastruktur online dan peserta tersedia. Pelatihan bagi UMKM akan dilakukan di platform Zoom (https://sl.ut.ac.id/Abdimas-AKT-030721) mulai pukul 09.00 hingga $12.00 \mathrm{WIB}$ pada tanggal 3 Juli 2021. Pemilihan waktu dan lokasi disesuaikan dengan waktu luang peserta pelatihan dan tidak mengganggu aktivitas sehari-hari. Peserta diberikan link pendaftaran sebelum diberikan materi oleh tim instruktur untuk mengetahui jumlah pendaftar yang ada dan untuk mendapatkan gambaran awal kemampuan masing-masing peserta dalam menangkap konten yang akan disajikan.

Para narasumber mengidentifikasi dan menganalisis semua tantangan yang dialami oleh UMKM pada akhir sesi program pengabdian kepada masyarakat, yang dimulai dengan presentasi sumber yang menguraikan masalah permodalan yang dihadapi UMKM selama ini. Setelah itu dilakukan sesi tanya jawab dengan meminta peserta mengaktifkan microphone dan mengajukan pertanyaan atau tanggapan. Hal ini penting untuk memastikan bahwa materi yang diberikan dapat diterima dengan baik. Agar peserta pelatihan tidak bosan saat mempelajari konten, tim instruktur membuat kuis dan pertanyaan dengan door reward untuk mereka selesaikan. Terakhir, sebelum pelatihan berakhir, tim dan seluruh peserta yang terlibat melakukan foto massal sebagai bukti dokumentasi yang akan disertakan dalam laporan pertanggung jawaban.

\section{Kesimpulan dan saran}

Beberapa poin kesimpulan dari penyelenggaraan pengabdian kepada masyarakat ini sebagai berikut:

1. Secara garis besar, penyelenggaraan pengabdian kepada masyarakat terlaksana dengan berhasil sebagaimana maksud dan tujuan Pengabdian kepada Masyarakat Program Studi Akuntansi Fakultas Ekonomi Universitas Terbuka.

2. Berdasarkan temuan pelatihan, ditemukan bahwa pelaku UMKM di Provinsi Banten masih memiliki pengetahuan akuntansi yang rendah. Oleh karena itu, pelatihan berkelanjutan dalam penyusunan laporan keuangan diperlukan.

3. Pelaku UMKM telah membuat laporan keuangan tercatat, namun masih merupakan proses yang relatif mendasar. Kami, penulis, mengusulkan agar kedepannya pelatihan pembukuan UMKM secara berkesinambungan diberikan, sehingga para pelaku UMKM dapat memelihara pembukuan yang baik untuk usahanya. Selain tersedianya laporan keuangan yang terstandarisasi, diharapkan para pelaku UMKM dapat memperoleh permodalan dari sektor perbankan, sehingga dapat mengembangkan usahanya. Pemilik usaha UMKM dapat memenuhi standar aplikasi pinjaman dengan akuntansi yang tepat. 


\section{Referensi}

Badria, N., \& Diana, N. (2018). Persepsi Pelaku UMKM Dan Sosialisasi SAK EMKM Terhadap Diberlakukannya Laporan Keuangan Yang Berbasis SAK EMKM 1 Januari 2018 (Studi Kasus Pelaku UMKM Se-Malang). Jurnal Ilmiah Riset Akuntansi, 7(01).

International Finance Corporation. (2016). Women-Owned SMEs in Indonesia: A Golden Opportunity for Local Financial Institutions. https://doi.org/10.1596/25403

ILO. (2019). Financing Small Businesses in Indonesia: Challenges and Opportunities. Jakarta

Kemenkoekonomi RI. (2021). UMKM Menjadi Pilar Penting dalam Perekonomian Indonesia. https://ekon.go.id/publikasi/detail/2969/umkm-menjadi-pilar-penting-dalam-perekonomianindonesia. Diakses pada Jumat, 3 Desember 2021 pukul 14.15 WIB.

Kemenkop UKM RI. (2021). Data UMKM Provinsi Banten. http://umkm.depkop.go.id/. Diakses pada Jumat, 3 Desember 2021 pukul 15.16 WIB

Noor, I. H. (2010). Penelitian dan pengabdian masyarakat pada perguruan tinggi. Jurnal Pendidikan dan Kebudayaan, 16(3), 285-297.

Pustapa, P., Riandra, A., \& Aisyah, R. (2019). Pelatihan Akuntansi Keuangan Bagi UMKM Kota Madya Medan. Jurnal Pengabdian kepada Masyarakat Nusantara, 1(1), 8-12.

UNDP., \& LPEM FEB UI. (2020). Impact of COVID-19 Pandemic on MSMEs in Indonesia. Jakarta

Utama, A. A. G. S., \& Pratama, D. (2019). Pengabdian masyarakat Desa Taman Sari: Optimalisasi kinerja UMKM melalui pelatihan akuntansi sederhana. In Prosiding Seminar Nasional Hasil Penelitian LPPM Universitas PGRI Madiun (pp. 357-360).

Riduwan, A. (2016). Pelaksanaan kegiatan pengabdian kepada masyarakat oleh perguruan tinggi. Ekuitas (Jurnal Ekonomi dan Keuangan), 3.

Risal, R., Wulandari, R., \& Jaurino, J. (2020). Pendampingan Akuntansi Dan Keuangan BUMDes Sedahan Jaya Kecamatan Sukadana Kabupaten Kayong Utara. Cendekia: Jurnal Pengabdian Masyarakat, 2(1), 49-57.

Rudiantoro, R., \& Siregar, S. V. (2012). Kualitas laporan keuangan umkm serta prospek implementasi SAK ETAP. Jurnal Akuntansi dan Keuangan Indonesia, 9(1), 1-21.

Widaninggar, N., \& Sari, N. K. (2018). Penerapan Sistem Akuntansi Dasar Dan Pelaporan Keuangan KPRI “Kencana”. Jurnal Pengabdian Masyarakat Ipteks, 4(2), 102-109.

Widyastuti, P. (2017). Pencatatan Laporan Keuangan Berbasis Standar Akuntansi Keuangan Entitas Tanpa Akuntabilitas (SAK ETAP) Pada Usaha Mikro Kecil Menengah (UMKM) di Bidang Jasa. Journal For Business And Entrepreneurship, 1(1). 